\title{
Kristus dan Krisna: Upaya Menemukan Point of Contact Dalam Mendialogkan Injil
}

Paulus Purwoto,

Sekolah Tinggi Teologi Torsina

pauluspurwoto022@gmail.com

David Eko Setiawan,

Sekolah Tinggi Teologi Tawangmangu

davidekosetiawan14217@gmail.com

Kalis Stevanus

Sekolah Tinggi Teologi Tawangmangu

kalisstevanus91@gmail.com

\begin{abstract}
The religious comparative dialogue is one of the effective means of carrying out the mission of the church, in the midst of a pluralistic society, especially for followers of the Hindu religion. An interesting concept in Christianity and Hinduism that can be compared is about Krishna and Christ. This study aims to make a comparison about the person of Christ and Krishna, and to interpret the concept of salvation they offer as an effort to find a point of contac in the dialogue of the Gospel to Hindu people in Indonesia. This study uses a library research method where the researcher tries to answer the research problem by looking for literature sources that correlate with the research problem, both textbooks and journals. The conclusion of this study is that there is a meeting point in the concept of salvation between Christ and Krishna which is useful in dialoguing the gospel to Hindu adherents in Indonesia.
\end{abstract}

\section{Keywords: Christ, Krishna, Gospel, Point of Contact}

\begin{abstract}
Abstrak
Dialog komparasi keagamaan merupakan salah satu sarana yang efektif bagi pelaksanaan misi gereja, ditengah masyarakat mejemuk khususnya terhadap penganut agama Hindu. Konsep yang menarik dalam agama Kristen dan Hindu yang dapat dilakukan komparasi adalah tentang Krisna dan Kristus. Penelitian ini bertujuan untuk melakukan komparasi tentang pribadi Kristus dan Krisna, serta memaknai konsep keselamatan yang mereka tawarkan sebagai sebuah upaya untuk menemukan point of contact dalam mendialogkan Injil kepada umat Hindu di Indonesia. Penelitian ini menggunakan metode penelitian kepustakaan (library research) dimana peneliti berusaha menjawab permasalahan penelitian dengan mencari sumber-sumber literatur yang berkorelasi dengan masalah penelitian baik buku teks, maupun jurnal. Kesimpulan penelitian ini adalah terdapat titik temu di dalam konsep keselamatan antara Kristus dan Krishna yang berguna dalam mendialogkan Injil kepada penganut Hindu di Indonesia.
\end{abstract}

Kata Kunci: Kristus, Krishna, Injil, Point of Contact 


\section{Pendahuluan}

Pewartaan Injil bagi segala bangsa merupakan Amanat Agung Kristus yang wajib dilaksanakan bagi setiap orang percaya. Hal tersebut seharusnya bukan menjadi sebagai beban melainkan menjadi sebuah kesukacitaan. Dalam perspektif Perjanjian Baru, misi dimulai dari sebuah ledakan kesukacitaan yang merupakan semacam jatuhan radioaktif yang tidak mematikan tetapi memberi kehidupan (Newbigin, 2010). Pewartaan Injil dasarnya dilaksanakan di tengah-tengah masyarakat majemuk dengan berbagai latar belakang kehidupan. (Newbigin, 2010) Berdasarkan konteks tersebut, tentunya gereja perlu untuk mencari metode yang tepat dalam mendialogkan Injil kepada mereka agar ditemukan suatu pola yang lebih kontekstual dan Alkitabiah. Melalui perbandingan tokoh dan ajaran agama-agama, diharapkan dapat menemukan Point of Contact sebagai titik berangkat dalam mendialogkan Injil secara kontekstual.

Mendialogkan Injil kepada para penganut agama lain di Indonesia telah terjadi sejak lama. Khusus kepada masyarakat penganut agama Hindu, dialogi antara Injil dengan mereka telah menyejarah. Hal tersebut telah menarik perhatian Supri untuk meneliti tentang penginjilan dan faktor konversi agama pada masyarakat Hindu di Bali (Surpi, 2012). Penelitian ini hanya berusaha mengungkap sejarah terjadinya penginjilan dan faktor-faktor yang melatarbelakangi konversi agama tersebut. Peneliti lain yang juga berusaha mencari titik temu dalam dialog Injil degan para penganut Hindu adalah Supradnyana, dimana dalam penelitiannya menemukan point of contact antara Yesus, Sang penunggang kuda putih dalam kitab Wahyu 9:11-21 dengan Awatara Sang Hyang Widi (Supradnyana, 2015). Penelitian bertujuan menjelaskan Yesus kepada masyarakat Hindu di Sulawesi Tengah dengan membingkainya dalam pemahaman orang Bali.

Beberapa penelitian di atas relevan dengan penelitian yaitu memiliki kesamaan obyek penelitian tentang pengkomunikasian Injil terhadap para penganut agama Hindu. Namun demikian terdapat juga perbedaan di dalamnya. Penelitian ini lebih berfokus pada pencari point of contact dengan membandingkan pribadi dan ajaran keselamatan yang ditawarkan Kristus dan Krisna. Melaluinya diharapkan ditemukan titik berangkat yang sama dalam menyeberangkan pesan Injil kepada masyarakat penganut agama Hindu. Adapun problem research dalam tulisan ini adalah point of contact apakah yang dapat ditemukan melalui perbandingan antara Kristus dan Krisna dalam mendialogkan Injil kepada para penganut Hindu di Indonesia?

\section{Metode}

Penelitian ini menggunakan metode Library Research. Melaluinya peneliti berusaha menjawab permasalahan penelitian dengan mencari sumber-sumber literatur yang berkorelasi dengan masalah penelitian. Sumber-sumber tersebut adalah buku teks, baik buku fisik maupun e-books, dan jurnal. Pendekatan tematis digunakan untuk 
mendeskripsikan dan mengkomparasikan tentang Kristus dan Krisna untuk memahami tentang pribadi Kristus dan Krisna, konsep keselamatan menurut Kristus dan Krisna, dan relevansi dari ajaran Kristus dan Krisna yang bisa dijadikan sebagai point of contact dalam mendialogkan Injil kepada penganut agama Hindu di Indonesia. Kemudian peneliti menganalisis sumber-sumber yang terkait dengan menggunakan analisis dokumen/analisis isi yang merupakan kajian yang menitikberatkan interpretasi bahan tertulis berdasarkan konteksnya untuk mendapatkan jawaban atas masalah penelitian.

\section{Hasil dan Pembahasan}

\section{Kristus dan Krisna: Sebuah Komparasi}

Pada bagian ini akan dibandingkan pribadi Kristus dalam perspektif Kekristenan dan Krisna dalam perspektif Hindu, dengan tujuan untuk menemukan persamaan dan perbedaan dari kedua sosok besar dari masing-masing agama tersebut.

\section{Kristus Dalam Perspektif Kekristenan}

Kristus adalah tokoh sentral dalam perspektif iman Kristen, olehnya untuk memahami teologi Kristen dengan benar, parameter utamanya adalah pemahaman yang benar tentang Kristus secara Alkitabiah. Pengenalan tentang Kristus secara benar merupakan inti teologi Kristen. (Ho, 2015) Dalam perspektif teologi Kristen, Yesus Kristus diyakini sebagai sepenuhnya manusia dan sepenuhnya Allah, bukan sebagian Allah dan sebagian manusia. Dalam satu oknum Yesus Kristus tinggal sifat ilahi sepenuhnya dan sifat manusia, surga dan bumi berhimpun bersama-sama didalam oknum yang menakjubkan. Stevanus menyatakan bahwa klaim Yesus sebagai Allah adalah benar sebagaimana yang dinyatakan di dalam teks-teks Injil. Ia menegaskan keilahianNya dengan menjalankan fungsi-fungsi, dengan asumsi hak prerogatif, atau menerima penghormatan yang benar-benar hanya milik Allah saja. (Stevanus, 2020) Konsep tentang keilahiaan Kristus tertulis dalam banyak ayat di Alkitab, baik dalam berita nubuatan dalam Perjanjian Lama, pernyataan Yesus Kristus sendiri, maupun pernyataan para murid Kristus.

Dalam Kitab Perjanjian Lama, Yesus Kristus merupakan sentral pemberitaan para nabi, dimana para Nabi Perjanjian Lama dari masa ke masa memberitakan nubuatan tentang lahirnya Mesias sang penebus dan pembebas. Dalam Kitab kejadian pasa 1: 1-3 realitas tentang Allah yang monotheisme Trinitarian itu dinyatakan sebagai Allah, Roh Allah dan Firman Allah. Sebelum kedatangan Allah dalam cara baru kedalam sejarah umat manusia, Firman Allah sudah ada dari kekal, serta berfungsi sebagai yang menyatakan Allah. 
Menzies dan Horton menulis menulis bahwa sangat mungkin teofani (penampakan diri Allah) di Perjanjian Lama sebenarnya adalah "Christofani), karena dalam keadaan pra-eksistensi-Nya, pertemuan singkat Yesus Kristus dengan orang-orang untuk menyatakan kehendak Allah akan sesuai sekali dengan tugas-Nya sebagai Yang Menyatakan (Stevanus, 2020). Dalam Kejadian 48:16, menunjuk kepada utusan sorgawi tersebut sebagai orang yang menebus atau menyelamatkan. Dalam Kitab Habakuk 13:1622, tampak jelas bahwa malaikat Teofani tersebut merupakan manifestasi dari Kristus. Manifestasi-manifestasi serta nubuatan Kitab Perjanjian lama tentang Kristus menunjuk tentang inkarnasi Kristus ke dalam dunia.

Keilahian Yesus Kristus dinyatakan oleh malaikat, dalam Lukas 2:11: “ Hari ini telah lahir bagimu Juruselamat, yaitu Kristus, Tuhan, di kota Daud. Dalam Lukas 1 :33: “...dan Ia akan menjadi raja atas kaum keturunan Yakub sampai selama-lamanya dan Kerajaan-Nya tidak akan berkesudahan." Juga terdapat dalam Lukas 1:35 Jawab malaikat itu kepadanya: "Roh Kudus akan turun atasmu dan kuasa Allah Yang Mahatinggi akan menaungi engkau; sebab itu anak yang akan kaulahirkan itu akan disebut kudus, Anak Allah. dari beberapa ayat tersebut nyata benar bahwa bukti keilahian Kristus dinyatakan oleh malaikat.

Keilahian Yesus Kristus juga dinyatakan oleh Yesus sendiri secara tersirat, ketika Ia berkata: "Barangsiapa telah melihat Aku, ia telah melihat Bapa" (Yoh. 14:9). Yesus menjalankan otoritas Ilahi yaitu mengampuni dosa (Mrk. 2:12), Ia juga disembah oleh banyak orang (Mat. 2:2,11; 14:33; 28:9). Pengakuan Yesus bahwa diri-Nya adalah Tuhan terdapat dalam Yohanes 13:13: "Kamu menyebut Aku Guru dan Tuhan, dan katamu itu tepat, sebab memang Akulah Guru dan Tuhan. Dari beberapa ayat tersebut nyata benar bahwa Yesus Kristus sendiri mengakui bahwa diri-Nya adalah Tuhan, hal ini membuktikan kelilahian Yesus.

Pernyataan keilahian Yesus Kristus juga nyata dalam ajaran Yohanes, dimana Injil Yohanes ditulis untuk menyatakan Yesus sebagai Anak Allah yang kekal, praeksisten, yang menjadi manusia untuk menyatakan kemuliaan Bapa dan membawa hidup kekal melalui kematian dan kebangkitan-Nya (Boice, 2015). Fakta bahwa Yesus adalah Allah secara tegas dinyatakan oleh Yohanes pada awal kitab: "Pada mulanya adalah Firman; Firman itu bersama-sama dengan Allah dan Firman itu adalah Allah. Ia pada mulanya bersama-sama dengan Allah." (Yoh. 1:1-2). Dari ayat tersebut secara implisit setidaknya terdapat tiga pernyataan Yohanes tentang keilahian Yesus: pertama, Yohanes sedang merujuk kepada masa lampau, dengan mundur jauh ke belakang sebelum kehidupan-Nya di bumi, bahkan sebelum permulaan penciptaan, ke dalam kekekalan. Kedua, peneguhan kepribadian Kristus adalah Allah sepenuhnya, bahkan Yesus sepenuhnya ilahi dalam segala hal (Boice, 2015). 
Secara eksplisit Yohanes menyatakan tujuan menulis Injil: "Memang masih banyak tanda lain yang dibuat Yesus di depan mata murid-murid-Nya, yang tidak tercatat dalam kitab ini, tetapi semua yang tercantum di sini telah dicatat, supaya kamu percaya, bahwa Yesuslah Mesias, Anak Allah, dan supaya kamu oleh imanmu memperoleh hidup dalam nama-Nya. (Yohanes 20:30-31). Dari fakta-fakta diatas, jelas bahwa bukti keilahian Yesus dinyatakan oleh Yohanes sebagai murid-Nya yang pertama, yang hadir secara fisik bersamaan dengan Yesus yang dapat menjadi saksi yang sahih.

Tidak diragukan lagi bahwa Paulus adalah teolog besar dari gereja mula-mula. Paulus menyatakan pemahaman tentang Yesus ketika menulis surat kepada jemaat Filipi, khususnya dalam Filipi 2:5-11. Dalam bagian tersebut, Paulus menelusuri kehidupan Kristus dari kekekalan masa lampau, ketika Ia ada dalam rupa Allah dan sama dengan Allah, peristiwa-peristiwa Kristus dibumi sampai pada masa kekekalan yang akan datang, dimana Kristus dimuliakan bersama Bapa (Boice, 2015). Dalam berbicara tentang Kristus, Paulus menggunakan dua kata Yunani yaitu morphe yang ditemukan dalam frasa "rupa Allah" (Ing.: the form of God) yang biasanya merujuk kepada bentuk luar dari sebuah obyek, yaitu kepada sesuatu yang eksterternal (Boice, 2015). Kata kedua adalah isos yang berarti "sama", dimana kata ini dalam bahasa Inggris ada dalam istilah ilmiah isomer, isomorph, isometric, dan isosceles triangle (Boice, 2015) Isomer adalah sebuah molekul yang memiliki struktur yang sedikit berbeda dengan molekul lainnya, tetapi sama dalam komposisi kimianya. Isomorph adalah sesuatu yang memiliki bentuk sama seperti sesuatu yang lain. Isometric berarti dalam ukuran yang sama, isosceles triangle (segitiga sama kaki) memiliki dua sisi yang sama. Penggunaan Paulus akan kata tersebut merujuk kepada Yesus, bahwa Yesus adalah sama dengan Allah.

Didalam perspektif teologi Kristen, fakta kedua yang sama pentingnya tentang Kristus adalah bahwa Ia adalah sepenuhnya manusia (Boice, 2015). Ke-Allahan-Nya adalah dari kekekalan masa lampau, sementara Kristus menjadi manusia pada satu titik tertentu dalam waktu melalui inkarnasi. Pniel Maiaweng menyataan bahwa Yesus telah membuktikan realitas kemanusiaan-Nya dalam realitas kehidupan-Nya sebagai manusia hidup. Ia memiliki natur manusia, menjalani proses persiapan sebelum melaksanaan pelayanan yang menjadi kehendak Bapa-Nya, menjalani kehidupan sosial yang memberkati banyak manusia, mempersiapkan para murid, dan klimaknya mati di kayu salib (Maiaweng, 2015). Senada dengan itu, Tutupoly menyatakan bahwa Kristus terbukti sebagai Allah dan sekaligus manusia sepenuhnya dalam teks Yohanes 1:1-18 (Tutupoly, 2018). Dalam Alkitab kebenaran tentang kemanusiaan Kristus tertulis dibanyak Kitab, hal tersebut meneguhkan konsep kemanusiaan Kristus Pada Perjanjian Lama terdapat berita nubuatan tentang kedatangan Kristus, yang mana natur ganda dari kedatangan Kristus tergambar secara jelas: "Sebab seorang anak telah lahir untuk kita, seorang putera telah diberikan untuk kita; lambang pemerintahan ada di atas bahunya, dan namanya 
disebutkan orang: Penasihat Ajaib, Allah yang Perkasa, Bapa yang Kekal, Raja Damai.” (Yesaya 9:5).

Dalam ajaran Yohanes natur ganda Kristus ini juga dinyatakn dengan jelas. Ungkapan "telah menjadi manusia" (sarks egeneto) dalam Injil Yohanes menunjukkan bahwa Firman yang berinkarnasi itu menjadi daging dalam kemanusiaan yang sejati, ini merupakan rahasia agung yang telah dinyatakan (Tutupoly, 2018)

Yohanes menggunakan pernyataan "eskenosen hemin" (diam diantara kita) untuk menjelaskan Inkarnasi Logos. Istilah "diam” (eskenosen) mempunyai struktur aoris indikatif aktif orang ketiga tunggal adalah kata kerja.Bentuk aoris disini menjelaskan suatu tindakan yng terjadi pada waktu tertentu. Hal ini berbicara tentang manifestasi yang tanpa waktu. Eskenosen ini muncul hanya dalam Yohanes 1: 14 dan kitab Wahyu. Eskenosen adalah bentuk istilah yang digunakan untuk menyatakan bahwa Logos mengambil tempat didalam "daging" (sarks). "Daging" Yesus (Logos adalah tempat yang baru untuk menyatakan kehadiran Allah di atas bumi. Secara tegas "eskenosen" menyatakan bahwa Firman sungguh menjadi daging dan "daging" adalah tempat berdiamnya Allah didalam Yesus Kristus secara jasmani (Rogers, 1998). Inkarnasi Logos/Kristus merupakan manifestasi Allah kepada manusia, supaya melalui Yesus Kristus, manusia dapat melihat dan mengenal Allah (Yoh. 1: 18).

Ajaran kemanusiaan Kristus juga muncul dalam tulisan-tulisan Paulus, dimana dalam tulisan-tulisannya Paulus sering membuat distingsi ketika menjelaskan tentang natur ganda dari Yesus. Alkitab tidak pernah ragu untuk menyatakan kebenaran kembar tentang keilahian penuh dan kemanusiaan sejati dari Kristus (Boice, 2015). Kepada orang Kristen di Roma, Paulus menulis: "tentang Anak-Nya, yang menurut daging diperanakkan dari keturunan Daud, dan menurut Roh kekudusan dinyatakan oleh kebangkitan-Nya dari antara orang mati, bahwa Ia adalah Anak Allah yang berkuasa, Yesus Kristus Tuhan kita.” (Roma 1:3-4). Hal yang senada juga ia tulis kepada jemaat di Galatia: "Tetapi setelah genap waktunya, maka Allah mengutus Anak-Nya, yang lahir dari seorang perempuan dan takluk kepada hukum Taurat. Ia diutus untuk menebus mereka, yang takluk kepada hukum Taurat, supaya kita diterima menjadi anak." (Gal. $4: 4-5)$.

Krisna Dalam Perspektif Hindu

Dalam bahasan berikut, peneliti akan mendeskripsikan tentang Krisna dalam perspektif agama Hindu. Cerita tentang Krisna terdapat dalam Bhagavadgita dan Mahabharata (Pattanaik, 2017). Berdasarkan kepercayaan tradisional menurut datadata dalam sastra dan perhitungan astronomi Hindu, hari kelahiran Krisna yang dikenal sebagai Janmashtami (Knott, 2016). Dalam Legenda Hindu Krisna adalah putra kedelapan dari Basudewa dan Dewaki, bangsawan dari kerajaan Surasena di India Utara 
yang diyakini merupakan salah satu dewa umat Hindu yang dipuja sebagai Awatara (inkarnasi) Dewa Wisnu yang ke delapan dari kesepuluh Awataranya (Sena, 2020).

Untuk memahami pribadi dan ajaran Krishna dengan baik haruslah dilihat dari perspektif inti ajaran Hindu secara benar. Inti dari ajaran Hindu dikonsepkan kedalam tiga kerangka dasar yakni filsafat (tattwa), etika (susila), dan upacara (yadnya) (Santika, 2017). Selain itu agama Hindu juga mengarkan tentang Panca Sradha (lima dasar keyakinan umat Hindu) yang melitputi Widhi Tattwa (keyakinan terhadap Tuhan Brahman), Atma Tattwa (keyakinan terhadap Atman Roh), Karmaphala Tattwa (keyakinan pada karmaphala atau hukum sebab-akibat), Punarbawa Tattwa (keyakinan pada kelahiran kembali atau reinkarnasi), dan Moksa Tattwa (keyakinan akan bersatunya Atman dengan Brahman) (Kartika, 2018). Secara umum ajaran agama hindu termuat dalam kitab kitab Weda.

Agama Hindu mengenal ajaran tentang Tuhan sebagai Brahmana Wdya, yang ditulis dalam kitab Brahma Widya. Di dalam kitab tersebut dibahas tentang Tuhan Yang Maha Esa, ciptaan-Nya, dan juga termasuk manusia dan alam semesta. Kitab Weda juga cabang dari Kitab Weda seperti Itihasa dan Purana, juga kitab-kitab Agama dan Darsana, menyebut Tuhan Yang Maha Esa dengan berbagai nama. Dalam kitab Weda, kita dapat temukan seribu nama Sri Wisnu, berdasarkan sifat dan kehebatan-Nya. Begitu pula dalam Bhagavad-Gita, misalnya, Krishna disebut dengan 27 nama dan gelar yang berbeda. Misalnya, Krishna disebur Hari (beliau yang menghilangkan segala penderitaan), Anantararupa (yang memiliki perwujudan yang jumlahnya tak terhingga); Krishna (maha menarik), Rama (sumber kebahagiaan), Hrisikesa (penguasa segala indria), Govinda (penyayang dan pelindung sapi), dan sebagainya (Suryanto, 1996).

Ajaran Agama dibagi ke dalam beberapa kelompok filsafat dari Wedanta; Waisnawisme, Saiwisme, Saktisme, serta memiliki berbagai kepercayaan dan aliran (Sivananda, 1996). Di dalam Hinduisme terdapat tiga golongan yang memuja Wisnu sebagai Tuhan disebut Waisnawa. Kedua, golongan yang memuja Siwa sebagi Tuhan yang disebut Saiwa. Dan yang ketiga adalah golongan Sakta, yang memuja Dewi atau aspek ibu dari Tuhan (Eka Suadnyana \& Ariyasa Darmawan, 2020).

Di dalam golongan Waisnawa terdapat golongan yang memuja Sri Krishna sebagai Tuhan yang tunggal dan tertinggi. Kelompok tersebut disebut Here Krishna. Secara etimologis Krishna berasal dari kata "Kris" dan "na". "Krish" berarti Maha Menarik, dan "na" artinya Maha Membahagiakan. Dengan demikian Krishna adalah Yang Maha Menarik dan Maha Membahagiakan. Bagi umat Hindu khususnya para penganut aliran Here Krishna (salah satu bagian kelompok agama Hindu, yang secara khusus mengajarkan umat Hindu untuk kembali kepada kesadaran Krishna) mendasarkan pemahaman mengenai Krishna pada kitab Bhagavad Gita dan kitab Purana (Nurhamidin \& Wardani, 2019). Namun yang membedakan antara agama Hindu dan 
aliran Here Krisna adalah prakteknya dalam mempercayai Trimurti tidak secara khusus melainkan hanya secara umum. Kerena menurut pengikut Here Krisna Trimurti adalah perwujudan dari Tuhan Krisna. Para pengikut ajaran Here Krisna memiliki satu tujuan hidup yaitu mengembalikan kesadaran dan keyakinan semua orang kepada tuhan Krisna sebagai entitas tertinggi, bahkan lebih tinggi dari Tri Murti. Dalam ajaran ini dapat dipahami bahwasanya posisi Tuhan Krisna dalam konsep teologis ajaran Here Krisna sangat supremasi melampaui posisi Sang Hyang Widi Wase yang oleh pemeluk agama Hindu pada umumnya disebut sebagai entitas tertinggi. Kedudukan Tri Murti yakni Syiwa, Brahma dan Whisnu dalam ajaran Here Krisna merupakan dewa-dewa yang diperintahkan Tuhan Krisna untuk mengatur alam semesta sesuai dengan tugas dan kedudukannya masing-masing.

Sri Krisna juga diyakini sebagai perwujudan keabadian, pengetahuan, dan kebahagiaan. Sri Krisna diyakini sebagai personalitas tertinggi Tuhan yang Maha Esa, yang mengendalikan segala ciptaannya sebagai jelmaanTuhan yang tidak memiliki asal muasal atau sumber, melainkan sumber segalanya dan sebab dari segala sesuatu dan merupakan kebenaran mutlak tertinggi dan perwujudan kebahagiaan abadi. Kedudukan Tri Murti yakni Syiwa, Brahma dan Whisnu dalam ajaran Here Krisna merupakan dewadewa yang diperintahkan Tuhan Krisna untuk mengatur alam semesta sesuai dengan tugas dan kedudukannya masing-masing.

\section{Komparasi Ajaran Keselamatan Versi Kristus dan Krisna}

Pengajaran tentang keselamatan merupakan hal yang selalu menarik untuk diperbincangkan dalam berbagai agama. Setiawan menulis bahwa keingintahuan setiap orang untuk memahami keselamatan jiwanya setelah mati, menjadi pendorong munculnya banyak pengajaran, isme ataupun gagasan tentang hal tersebut (Setiawan, 2019). Penelitian ini berusaha untuk mengkomparasikan kosep keselamatan menurut Kristus dan Krishna.

\section{Keselamatan Versi Kristus}

Keselamatan dalam teologi Kristen bersumber dari Allah. Rasul Paulus menyatakan hal tersebut sebagai berikut: "Sebab karena kasih karunia kamu diselamatkan oleh iman; itu bukan hasil usahamu, tetapi pemberian Allah, itu bukan hasil pekerjaanmu: jangan ada orang yang memegahkan diri. (Efesus 2:8-9). Berdasarkan ayat tersebut jelaslah bahwa keselamatan bersumber dari Allah, Dialah yang memberikan keselamatan kepada manusia, karena pada dasarnya manusia tidak mampu menyelamatkan dirinya sendiri.

Pernyataan keselamatan dalam Perjanjian Lama merupakan berita nubuatan Mesianik akan lahirnya seorang pembebas yang akan menjadi jalan keselamatan bagi 
setiap manusia yang percaya. Nubuatan Mesianik tersebut tergenapi dalam inkarnasi Kristus. Penelitian dibidang ini juga telah banyak dilakukan oleh peneliti terdahulu, mengingat betapa penting dan menariknya topik tersebut untuk dibahas. Teologi Kristen adalah suatu penjelasan siapa Kristus dan apa artinya beriman kepada Kristus (Setiawan, 2019). Alasan Allah berinkarnasi dalam karya teologis Anselm seperti dikutib Boice adalah bahwa Allah menjadi manusia dalam Kristus karena hanya Dia yang adalah Allah sekaligus manusia yang dapat menggenapkan keselamatan kita (Setiawan, 2019). Dari perspektif tersebut, inkarnasi menunjukkan kepada kita bahwa Allah mampu memahami manusia dan bersimpati dengan manusia.

Kristus harus berinkarnasi sebagai manusia, lahir, wafat dan dibangkitkan dengan satu tujuan utama yaitu sebagai korban penebus dosa seperti tertulis dalam Yesaya 53 dan teks-teks lain Perjanjian Lama berita tentang penderitaan Sang Pembebas yang akan datang diberitakan. Berita ini terus berlanjut hingga waktu yang ditentukan lahirlah Kristus sebagai manusia, wafat, dibangkitkan pada hari ke tiga sesuai dengan ketetapan Allah. Inkarnasi Kristus memiliki tujuan utama yaitu untuk penyelamatan manusia yang berdosa. Allah melihat bahwa tidak ada jalan lain bagi pendamaian selain dengan jalan inkarnasi.

Kristus secara tegas menyebut diri-Nya: "sebagai jalan keselamatan, dalam Yohanes 4:16 tertulis: "Kata Yesus kepadanya: "Akulah jalan dan kebenaran dan hidup. Tidak ada seorang pun yang datang kepada Bapa, kalau tidak melalui Aku." David Iman Santoso menulis bahwa, "Dalam Injil Yohanes ada tujuh kali ucapan "Aku Adalah..." (ego eimi) yang diucapkan oleh Tuhan Yesus. Ucapan-ucapan ini termasuk unik, yang disebut emphatic pronoun, yaitu ada penakanan "Aku”, yaitu Yesus, bukan orang lain yang mengatakan. Penekanan ini merupakan ciri penulisan Yohanes dan sekali lagi mempunyai makna Kristologis yang besar bagi person Kristus" (Santoso, 2014). Ini sebuah pernyataan yang tegas, berani dan penuh kepastian dimana Kristus menyatakan diri-Nya dengan frasa Aku adalah Jalan.

Yesus berkata, "Akulah Jalan", karena di dalam Dia manusia dibawa kembali kepada Allah, dan melalui Jalan Hidup itu, ia mencapai tujuan akhirnya yang sejati. Yesus adalah jalan satu-satunya menuju kepada Bapa. Tujuan akhir hidup manusia hanya didapatkan di dalam Yesus Kristus (Hia, 2020). Yesus tidak semata-mata menunjukkan jalan itu; Ia sendiri adalah jalan itu. Adalah benar bahwa Ia mengajarkan jalan itu (Mark 12:14; Luk 20:21), memimpin kita di dalam jalan itu (Luk 1:79), dan telah memberikan kita jalan yang baru dan hidup (Ibr 10:20); tetapi semua ini memungkinkan hanya karena Ia sendiri adalah jalan itu.

Keselamatan Versi Krishna 
Konsep keselamatan dalam agama Hindu tidak terpisahkan dari konsep tentang Tuhan. Eka menyebutkan bahwa Tuhan Yang Maha Esa dalam Hinduisme dikenal sebagai Isa yang bersifat impersonal dan berada diseluruh alam semesata, mengatur serta mengendalikanya(Adnyana, 2020).

Tuhan adalah sosok yang tak dapat dipikirkan, amat gaib, meresapi segala, berada dimana-mana, meliputi segala bagaikan api yang hanya satu dapat membakar semua yang ada di alam ini. Tuhan adalah intisari hakekat kebenaran yang tertinggi yang sulit digapai. Tuhan bergelar Ísāa adalah sumber asal mula dan kembalinya alam semesta beserta semua isinya. Sementara Percikan kecil dari Brahman atau Tuhan adalah ātman. Brahman ialah azas alam semesta sedangkan àtman adalah azas pribadi atau individu. Brahman atau Tuhan memiliki hakekat yang mutlak yang bebas dari segala sesuatu disebut Sambhūti dan makhluk ciptaan Tuhan seperti para Dewa

Dari perspektif ajaran tentang keselamatan diatas jelas bahwa dalam perspektif Hindu untuk memperoleh keselamatan seseorang harus berjuang dengan kekuatan dirinya supaya terbebas (berkarma) untuk kehidupannya dengan menggunakan senjata pamungkas yaitu Vidya (pengetahuan) untuk mengalahkan Avidya (ketidak tahuan) sebagai penyebab kesengsaraan.

Dalam beberapa teks Upanisad dan Bagavadgita, Krsihna menyatakan dirinya sebagai Jalan Setapak. Konsep tentang Jalan Setapak sebagai konsep keselamatan Krisnha tedapat dalam perkataan Krsina di Bhagawadgita dan Upanisad tentang Path atau Jalan Setapak yang akan berakhir kepadanya bila seseorang mencintainya. Konsep tersebut merupakan sebuah terobosan bagi kebuntuan seseorang untuk keluar dari penjara karma yang menindih kehidupan umat manusia. I Wayan Sapta menulis bahwa Karma dalam arti sempitnya adalah perbuatan, secara luas adalah hukum sebab akibat atau buah dari segala perbuatan yang disebut karma phala (Wigunadika, 2018). Dari pernyataan tersebut nyata bahwa hukum karma bersifat universal, dalam artian bahwa semua mahluk tunduk dibawah hukum karma, dan setiap manusia akan menuai dari semua hasil perbuatannya, baik bersumber dari pikiran, ucapan dan perbuatan. Ajaran Karma Pala menjadi merupakan menjadi pilar keyakinan dalam teologi Hindu (Wigunadika, 2018).

Dalam Upanisad dinyatakan tentang pentingnya seseorang memperhatikan kehidupan kekal demikian: "God allowed man to look outward, but seeing the outher, the inner was ignored. Some wise man seeking eternal life turned his sight within, and beheld his own spiri" (Hooper et al., 2007). Dari pernyataan Krisnha tersebut jelas bahwa dalam perspektif teologi Hindu setiap manusia boleh saja mengejar semua hal-hal yang bersifat duniawi atau dunia luar, namun demikian jangan melupakan hal-hal yang bersifat rohani (bagian dalam) yaitu kehidupan kekal. Untuk mencari kehidupan kekal beberapa orang bijak berupaya meninggalkan keduniawian dan mengalihkan pandangannya kedalam dirinya sendiri, rohnya sendiri. 
Krishna adalah Jalan Setapak. Selanjutnya Krishna menawarkan konsep Jalan Setapak sebagai jalan pada kebebasan, kelepasan atau keselamatan . Konsep Jalan Setapak tersebut dalam Bagavad Gita dengan mengatakan: " many are the paths of men, though all those paths end in Me for those who love Me" (Hooper et al., 2007). Dalam perspektif Krishna sesungguhnya banyak jalan yang dapat dilalui manusia, khususnya Jalan Setapak yang akan berakhir kepadanya jika seseorang itu mencintainya. Konsep tersebut merupakan bagaikan seteguk air yang menyejukkan seseorang yang tengah kehausan dipadang belantara yang gersang. Dengannya Krishna menawarkan harapan ditengah lingkaran karma yang menjadi pergumulan umat sepanjang masa.

Bagavad Gita menerangkan bahwa Krishna adalah Sumber Terang. Krishna menyatakan bahwa: "The light wich resides in the sun and shines on all...is My light. Entering the earth with My energy, I Support all beings, and I nourish all the herbs, becoming the watery moon (Hooper et al., 2007) . Dalam pernyataan tersebut, dapat diinterpretasikan bahwa Krishna merupakan sumber cahaya yang akan menerangi perjalanan manusia untuk keluar dari karma dan kesengsaraan melalui Jalan Setapak bagi setiap orang yang mengejar Vidya dan mencintainya.

Beberapa pernyataan Krishna sehubungan dengan konsep teologi jalan setapak adalah sebagai berikut: "Whoever comes to Me for Shelter, they will all reach the Way supreme " - Bagavad Gita” (terjemahan bebas: Siapapun yang datang kepada-Ku untuk mencari perlindungan, mereka semua akan mencapai Jalan tertinggi) (Hooper et al., 2007). Pernyataan berikutnya terdapat dalam Upanisad demikian: "When the five senses and the mind are stilled, when the reasoning intelek rests in silence, then begins the highest path. (The Katha Upanisad (Hooper et al., 2007). Dalam beberapa pernyataan dalam Bagavad Gita dan Upanisad tersebut meneguhkan konsep teologi jalan setapak (The Path Teologi) yang ditawarkan oleh Krishna sebagai upaya untuk melepaskan diri dari lingkaran inkarnasi yang disebabkan oleh karma setiap manusia.

The Theology of Path: Sebuah Point Of Contact Dalam Mendialogkan Injil.

Seperti peneliti paparkan diatas, bahwa komparasi perbandingan keagamaan ini dimaksudkan untuk menemukan titik temu misi kontekstual bagi penganut agama Hindu khususnya aliran Hindu Hare Krishna yang merupakan bagian dari sakta Waisnawa, yang mana aliran ini memuja Sri Krishna sebagai Tuhan tunggal dan yang tertinggi. Nicholls seperti dikutip oleh David Hasselgrave dan Edward Rommen, menulis bahwa kontekstualisasi adalah penerjemahan isi Injil Kerajaan yang tidak berubah ke dalam bentuk lisan yang bermakna bagi bangsa-bangsa dalam budaya mereka dan dalam situsai-situasi eksistensial mereka (Hesselgrave, 2004).

Konsep pengajaran tentang Teologi Jalan sesuai ajaran Kristus dan konsep pengajaran tentang Jalan Setapak (the Path) dalam penelitian ini disebut sebagai The 
Path Teology atau Teologi Jalan Setapak yang sama-sama ditawarkan oleh Kristus dan Krishna sebagai solusi keselamatan bagi para penikut-Nya. Konsep tersebut dapat dijadikan point of contac bagi usaha misi kontekstual diamana dalam kedua agama memiliki konsep yang hampir sama namun berbeda, berbeda namun hampir sama.

Dalam agama Kristen dan Hindu sama-sama memiliki konsep tentang keselamatan, walaupun konsep keselamatan Hindu jelas berbeda dengan konsep keselamatan dalam ajaran Kristus. Dalam soteriologi Kristen dinyatakan jelas di dalam Alkitab, dimana keselamatan dipandang sebagai anugrah Allah (Ef. 2:8-9) dan bukan merupakan usaha dari manusia (Setiawan, 2018). Sementara dari perspektif soteriologi Hindu untuk memperoleh keselamatan seseorang harus berjuang dengan kekuatan dirinya supaya terbebas (berkarma) untuk kehidupannya dengan menggunakan senjata pamungkas yaitu Vidya (pengetahuan) untuk mengalahkan Avidya (ketidak tahuan) sebagai penyebab kesengsaraan (Adnyana, 2019). Perbedaan utama terletak pada cara memperoleh keselamatan, dimana menurut Kristen keselamatan merupakan anugrah Allah, sementara menurut Hindu keselamatan adalah upaya perjuangan manusia menurut kekuatannya sendiri.

Konsep The Path Teology merupakan solusi yang sama-sama ditawarkan oleh Kristus dan Krishna, namun demikian terdapat perbedaan yang mencolok tentang kepastian keselamatan diantara jalan yang mereka tawarkan. Kristus memiliki tawaran yang tidak spekulatif, melainkan penuh kepastian karena di dalam Dia manusia dibawa kembali kepada Allah, dan melalui Jalan Hidup itu, ia mencapai tujuan akhirnya yang sejati. Yesus adalah jalan satu-satunya menuju kepada Bapa. Tujuan akhir hidup manusia hanya didapatkan di dalam Yesus Kristus (Hia, 2020). Dalam perspektif Krishna sesungguhnya banyak jalan yang dapat dilalui manusia, khususnya Jalan Setapak yang akan berakhir kepadanya jika seseorang itu mencintainya. Ungkapan tersebut memang memberikan secercah harapan ditengah pergumulan umat Hindu untuk keluar dari lingkaran inkarnasi yang diakibatkan oleh karma dari setiap orang, namun tidak terdapat pernyataan yang tegas baik dalam Bhagavadgita maupun Upanisad yang menjelaskan tentang kepastian keselamatan yang ditawarkan oleh Krishna.

\section{Kesimpulan}

Kristus dan Krishna merupakan tokoh sentral dalam Agama Kristen dan Hindu khususnya aliran Hindu Hare Krishna yang merupakan bagian dari sekte Waisnawa, yang mana aliran ini memuja Sri Krishna sebagai Tuhan tunggal dan yang tertinggi. Kedua agama memiliki keyakinan yang sama dimana setiap manusia memerlukan keselamatan (Kristen) dan kelepasan atau kebebasan dari karma (Hindu) dan keduanya menawarkan The Path Theology atau Teologi Jalan Setapak sebagai jalan keselamatan. Beranjak dari hal tersebut, Injil dapat didialogkan kepada para penganut Hindu dengan lebih 
kontekstual. Mengingat gagasan tentang "Jalan" sudah dikenal oleh mereka, sehingga gagasan ini dapat menjadi point of contact dalam mendialogkan Injil.

\section{Daftar Rujukan}

Adnyana, P. E. S. (2019). Brahma Vidyā Dalam Kitab Íśā Upaniṣad (Studi Teologi Hindu). Jurnal Pangkaja: Program Pascasarjana Institut Hindu Dharma, 22(2).

Adnyana, P. E. S. (2020). Brahma Vidyā Dalam Kitab İsā Upaniṣad (Studi Teologi Hindu). Jurnal Pangkaja : Jurnal Agama Hindhu, 22(2), 44-54.

Boice, J. M. (2015a). Dasar-Dasar Iman Kristen. Penerbit Momentum (Momentum Christian Literature).

Boice, J. M. (2015b). Dasar-dasar Iman Kristen (Foundations of Christian Faith) (S. Yo (Ed.); Cetakan Ke). Penerbit Momentum (Momentum Christian Literature).

Eka Suadnyana, I. B. P., \& Ariyasa Darmawan, I. P. (2020). Nilai Pendidikan Agama Hindu Dalam Lontar Siwa Sasana. Cetta: Jurnal Ilmu Pendidikan, 3(2), 371-391. https://doi.org/10.37329/cetta.v3i2.460

Hesselgrave, D. J. (2004). Communicating Christ Cross-Culturally: Mengomunikasikan Kristus Secara Lintas Budaya. Malang Literatur SAAT.

Hia, Y. (2020). Makna Ungkapan Ego Emi Dalam Yohanes 11:25 Dan 14:6. Phronesis, Volume $3 \mathrm{~N}$.

Ho, R. W. (2015). Siapakah Kristus (Cetakan-1). Penerbit Andi.

Hooper, Richard, \& Ed. (2007). Jesus, Buddha, Krishna, Lao Tzu: The Parallel Sayings: the Common Teachings of Four World Religions. Sanctuary Publications.

Kartika, N. G. A. (2018). Peningkatan Mutu Komunikasi Pemuda Yang Beretika Dan Cerdas Dengan Semangat Ajaran Veda. Jurnal Penjaminan Mutu, 4(1), 101. https://doi.org/10.25078/jpm.v4i1.403

Knott, K. (2016). Hinduism: a very short introduction (second edi). Oxford University Press. 
Maiaweng, P. C. D. (2015). Inkarnasi:Realitas Kemanusiaan Yesus. Jurnal Jaffray, Volume 13. https://doi.org/DOI: http://dx.doi.org/10.25278/jj71.v13i1.114

Newbigin, L. (2010). Injil Dalam Masyarakatmajemuk(S. R. B. G. Mullia (Ed.); Cetakan ke). BPK Gunung Mulia.

Nurhamidin, B., \& Wardani, A. K. (2019). Relasi Agama dan Negara dalam Gerakan Keagamaan Baru: Studi Kasus Komunitas Here Krisna Yogyakarta. FUADUNA : Jurnal Kajian Keagamaan Dan Kemasyarakatan, 3(2), 106. https://doi.org/10.30983/fuaduna.v3i2.2513

Pattanaik, D. (2017). Krishna's Secret (First Publ). westland publications ltd.

Rogers, C. L. (1998). The New Linguistic Exegetical Key to the Greek Testament. Zondervan Publishing House.

Santika, N. W. R. (2017). Pemahaman Konsep Teologi Hindu (Perspektif Pendidikan Agama Hindu). Jurnal Bawi Ayah, 8(1), 63-82.

Santoso, D. I. (2014). Theologi Yohanes: Intisari Dan Aplikasinya. SAAT.

Sena, I. G. M. W. (2020). Relasi Manusia, Alam dan Tuhan Dalam Harmonisasi Semesta. Sphatika: Jurnal Teologi, 9(1), 15. https://doi.org/10.25078/sp.v9i1.1598

Setiawan, D. E. (2018). Konsep Keselamatan Dalam Universalisme Ditinjau Dari Soteriologi Kristen: Suatu Refleksi Pastoral. Jurnal Fidei, 1(2), 250-269.

Setiawan, D. E. (2019). Refleksi Pastoral terhadap Konsep Keselamatan dalam Universalisme Ditinjau dari Soteriologi Kristen. Fidei: Jurnal Teologi Sistematika Dan Praktika, 1(2), 250-269. https://doi.org/10.34081/270031

Sivananda, S. S. (1996). Intisari Ajaran Hindu. Paramita.

Stevanus, K. (2020). Bukti Keilahian Yesus Menurut Injil. Jurnal Teruna Bhakti, Volume 2 N, 82-96. https://doi.org/DOI: https://doi.org/10.47131/jtb.v2i2.49

Supradnyana, I. G. (2015). Penunggang Kuda Putih Itu Adalah Ida Sang Hyang Yesus Kristus, Sang Awatara: Perjumpaan Kristen Bali dengan Kitab Wahyu di Sulawesi 
Tengah. Indonesian Journal of Theology, 1(July), 61-76.

Surpi, N. I. K. (2012). Penginjilan dan Faktor Konversi Agama Hindu ke Kristen Protestan di Kabupaten Badung Bali. Analisa: Journal of Social Science and Religion, 19(2), 159-170.

Suryanto. (1996). Hindu di Balik Tuduhan \& Prasangka. Paramita.

Tutupoly, L. (2018). Ketuhanan Dan Kemanusiaan Yesus Kristus Berdasarkan Injil Yohanes 1 : 1-18. Jurnal Pendidikan Agama Kristen Regula Fidei, 3, 482-496.

Wigunadika, I. W. S. (2018). Membangkitkan Kembali Karma Phala. Purwadita : Jurnal Agama Dan Budaya, 2(1). 